\title{
Upaya Peningkatan Pengetahuan melalui Promosi Kesehatan Penyakit Keganasan pada Anak di SMAN Titian Teras Jambi
}

\author{
Suryati $^{1}$, Suryadi Imran ${ }^{2}$, Devi Yusmahendra ${ }^{3}$, Apriani ${ }^{4}$ \\ ${ }^{1-4}$ Program Studi D3 Keperawatan, STIKes Garuda Putih Jambi \\ Email: suryatifrd@gmail.com
}

Submitted : 07/12/2021

Accepted: 08/01/2022

Published: 28/01/2022

\begin{abstract}
Malignant disease, or more commonly known as cancer, is a disease characterized by the growth and spread of abnormal cells in the body. Malignant disease in children, although rare, is the second leading cause of death in children in developed countries after accidents. Data from the Union for International Cancer Control (UICC), there are about 176,000 children worldwide who are diagnosed with cancer each year. In Indonesia, there are about 11,000 cases of childhood cancer every year. Recognizing the signs of malignancy at an early age can increase the cure rate and life expectancy of children who experience it. Therefore, it is necessary to provide knowledge to children about early detection and prevention of cancer in children. This activity is carried out by the method of providing health promotion in the form of counseling at SMAN Tititan Teras Jambi. This activity is carried out by the method of counseling. The activity has been carried out in October 2021. The output of this activity is an increase in student knowledge. The results of the activity evaluation, it was found that there were differences in the level of knowledge of students who were given counseling with students who were not given counseling (scores of 7.03 and 5.63, respectively). Increasing knowledge is expected to improve student attitude and behavior to recognize early signs \& symptoms of malignancy, so that diagnosisand management can be carried out quickly \& precisely.
\end{abstract}

Keywords : children, early detection, prevention of cancer

\begin{abstract}
abstrak
Penyakit keganasan, atau yang lebih banyak dikenal sebagai kanker, adalah penyakit yang ditandai oleh pertumbuhan dan penyebaran sel-sel abnormal dalam tubuh. Penyakit keganasan pada anak, walaupun kejadiannya jarang, merupakan penyebab kematian kedua terbanyak pada anak di negara maju setelah kecelakaan. Data Union for International Cancer Control (UICC), terdapat sekitar 176.000 anak di seluruh dunia yang didiagnosis kanker setiap tahunnya. Di Indonesia, terdapat sekitar 11.000 kasus kanker anak setiap tahunnya. Pengenalan tanda-tanda penyakit keganasan sejak dini dapat meningkatkan angka kesembuhan dan harapan hidup anak yang mengalaminya. Oleh sebab itu perlu dilakukan pemberian pengetahuan kepada anak tentang deteksi dini dan cara pencegahan kanker pada anak. Kegatan ini dilaksanakan dengan metode memberikan promosi kesehatan berupa penyuluhan. Kegiatan dilaksanakan pada bulan Oktober 2021 di SMAN Titian Teras Jambi. Luaran kegiatan ini adalah meningkatkan pengetahuan siswa. Hasil evaluasi kegiatan diperoleh setelah diberikan edukasi terjadi peningkatan pengetahuan siswa tentang tanda \& gejala penyakit keganasan, ada perbedaan tingkat pengetahuan siswa yang diberi penyuluhan dengan siswa yang tidak diberi penyuluhan (masing-masing scor 7.03 dan 5.63). Peningkatan pengetahuan diharapkan dapat meningkatkan sikap dan prilaku siswa untuk mengenali secara dini tanda \& gejala penyakit keganasan, sehingga bisa dilakukan penegakan doiagnosis dan penatalaksanaan secara capat \& tepat.
\end{abstract}

Kata kunci : anak, deteksi dini, pencegahan kanker 


\section{PENDAHULUAN}

Penyakit keganasan, atau yang lebih banyak dikenal sebagai kanker, adalah penyakit yang ditandai oleh pertumbuhan dan penyebaran sel-sel abnormal dalam tubuh. Jenis penyakit keganasan tergantung jenis sel tubuh yang berubah menjadi tidak normal. Terdapat dua jenis penyakit keganasan pada anak, yaitu tumor padat dan keganasan sel darah (leukemia). Jenis yang paling banyak dijumpai adalah keganasan sel darah. Penyakit keganasan pada anak dapat dijumpai sejak usia bayi (kurang dari satu tahun) hingga usia remaja.

\section{Menurut data Union for}

International Cancer Control(UICC), terdapat sekitar 176.000 anak di seluruh dunia yang didiagnosis kanker setiap tahunnya. Di Indonesia, terdapat sekitar 11.000 kasus kanker anak setiap tahunnya, dan sekitar 650 kasus kanker anak terjadi di Jakarta.

Ada sekitar 300 kasus baru penyakit keganasan pada anak tiap tahun yang berobat ke Rumah Sakit Umum Pusat Nasional Dr. Cipto Mangunkusumo. Angka ini berbeda-beda di tiap rumah sakit yang melayani pasien anak dengan penyakit keganasan. Kebanyakan di antaranya datang dengan stadium lanjut. Pada stadium lanjut, pengobatan terasa lebih berat karena penyakit telah menyebar ke banyak bagian tubuh sehingga menimbulkan gejala yang lebih berat. Harapan untuk penyembuhan juga lebih sulit pada penyakit kanker stadium lanjut.

Sifat penyakit keganasan pada anak berbeda dengan dewasa. Jenis keganasan yang ditemukan pada anak juga berbeda dengan dewasa. Beberapa di antaranya memberi respons yang lebih baik terhadap pengobatan, terutama bila diobati pada stadium dini. Tubuh anak juga lebih tahan terhadap efek samping kemoterapi. Kejadian penyakit keganasan pada anak sulit dicegah, namun untuk beberapa jenis keganasan, pengobatan yang dilakukan dengan tepat pada stadium awal dapat mencapai kesembuhan. Pengenalan tandatanda penyakit keganasan sejak dini dapat meningkatkan angka kesembuhan dan harapan hidup anak yang mengalaminya.

Kanker merupakan salah satu masalah kesehatan utama di Indonesia dikarenakan biaya pengobatan yang tinggi dan sering berakibat kematian. Untuk itu Pemerintah mengimbau agar masyarakat terus menerus membudayakan Perilaku Gerakan Masyarakat Hidup Sehat atau Germas.Pemerintah senantiasa berupaya meningkatkan jangkauan pelayanan kesehatan melalui pendekatan kepada masyarakat, yaitu kunjungan ke masyarakat secara periodik oleh tenaga kesehatan untuk deteksi dini masalah kesehatan, pengobatan segera penyakit, upaya promotif-preventif, dan penanggulangan faktor risiko kesehatan.

Seluruh lapisan masyarakat Indonesia berperan aktif dalam penanggulang kanker melalui deteksi dini serta pengobatan segera. Hal ini akan berpeluang pada meningkatnya angka kesembuhan dan angka harapan hidup.Tenaga kesehatan perlu menginformasikan secara intensif dan terus menerus agar masyarakat mendapatkan informasi tentang kanker dari tenaga kesehatan.

Berdasarkan latar belakang tersebut, kami tertarik melakukan pengabdian masyarakat melalui tidakan promosi kesehatan memberikan penyuluhan tentang deteksi dini penyakit keganasan pada anak \& remaja serta serta pencegahannya.

Tujuan dari kegiatan ini adalah untuk meningkatkanpengetahuananak \& remaja tentangdeteksi dini penyakit keganasan pada anak \& remaja serta pencegahannya serta dalam rangka melaksanakan tridharma perguruntinggi. Manfaat kegiatan ini diaharapkan dapat 
meningkatkan upaya deteksi dini penyakit kanker pada anak dan menurunkan angka kejadian penyakit kanker pada anak melalui tindakan pencehahan.

\section{TARGET \& LUARAN}

Khalayakyangmenjadisasarandala mkegiataniniadalah siswa-siswi kelasX SMANTitianTeras Jambi. Luaran yang diharapkan dari kegiatan pengabdian yang dilaksanakan berupa peningkatan pengetahuan, penerapan IPTEK (Penyakit Keganasan pada anak) di masyarakat yaitu anak sekolah dan publikasi di jurnal abdimas nasonal terdaftar ISSN atau terakreditasi.

\section{METODE PELAKSANAAN}

Waktu pelaksanaan pengabdian masyarakat ini dilakukan dari bulan Agustus samapai November 2021. Sebelum pelaksanaan kegiatan dilakukan terlebih dahulu penjajakan lokasi. Dalam penjajakan lokasi ini dimusyawarahkan mengenai waktu pelaksanaan kegiatan dengan memperhatikan masukandari kegiatan sekolah. Kegiatan yang dilaksanakan adalah berupa Penyuluhan deteksi dini penyakit keganasan pada anak \& remaja serta pencegahannya di SMAN Titian Teras Jambi.

\section{HASIL DAN PEMBAHASAN}

Kegiatan pengabdian masyarakat yang dilakukan pada siswa siswa kelas $\mathrm{X}$ yang berjumlah 248 orang siswa. Kegiatan yang dilakukan dengan mengumpulkan semua siswa kelas X SMAN Titian Teras Jambi. Kegiatan dilaksanakan di aula sekolah. Kegiatan dimulai tepat pukul 09.00 WIB sesuai perencanaan. Koordinasi dengan siswa d bantu guru pamong sekolah. Kegiatan diikuti dengan serius dan antusias seperti Gambar 1 berikut ini.

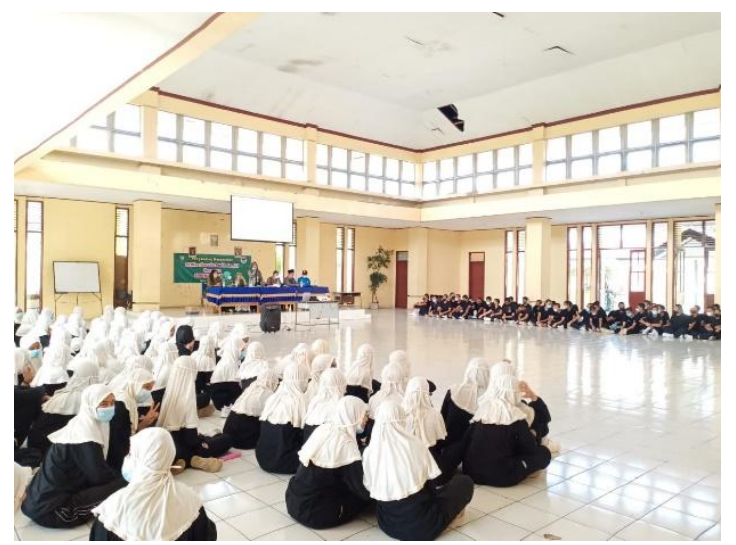

Gambar 1. Suasana saat penyuluhan kepada siswa kelas X SMAN Titian Teras

Kegiatan dibuka oleh kepala sekolah SMAN Titian Teras. Semua tim telah melaksanakan perannya masing masing sesuai tugas dan fungsi. Pihak sekolah turut memberikan dukungan dan partisipasi demi terlaksananya kegiatan ini. Hal ini terlihat pada gambar $3 \& 4$ berikut:

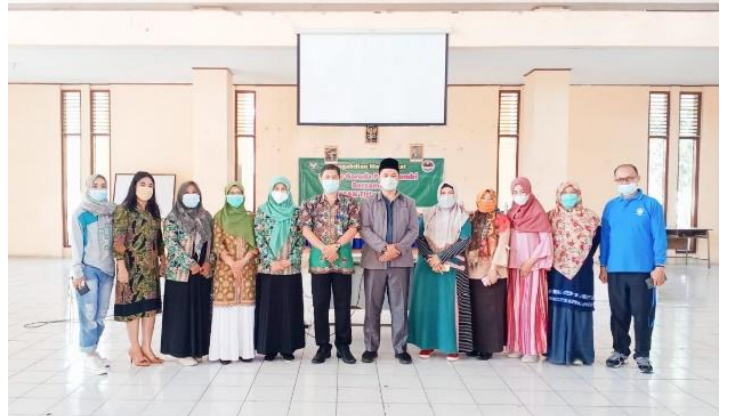

Gambar 3. Foto bersama tim pelaksana dengan kepala sekolah \& staff

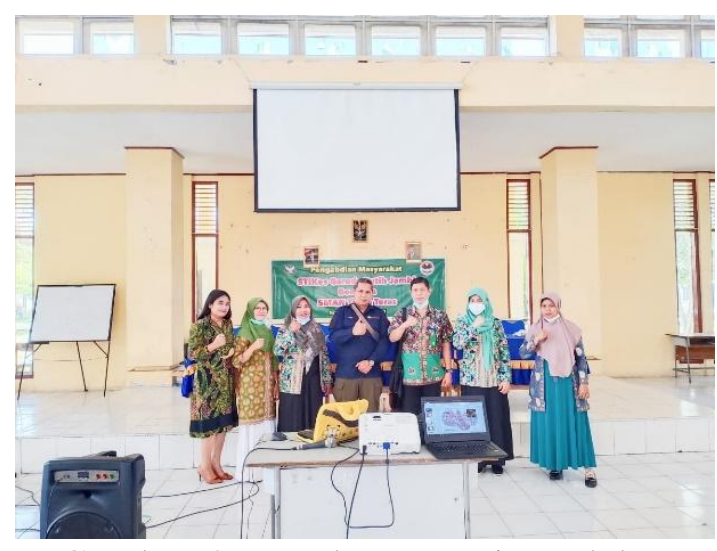

Gambar 4. Foto bersama tim pelaksana kegiatan pengabdian masyarakat

Evaluasi hasil pelaksanaan kegiatan penyuluhan dilakukan dengan mambagikan 
kuesioner evaluasi untuk melihat tingkat pengetahuan siswa kelas X SMAN Titian Teras Jambi tentang deteksi dini penyakit keganasan pada anak \& remaja serta pencegahannya.kemudian tingkat pengetahuan siswa yang telah mendapatkan penyuluhan dibandingkan dengan siswa yang tidak mendapat penyuluhan yang dilakukan pada siswa kelas XI SMAN Titian Teras Jambi.

Hasil questioner menunjukkan adanya perbedaan tingkat pengetahuan siswa yang mendapatkan penyuluhan tentang deteksi dini penyakit keganasan pada anak \& remaja serta pencegahannya dengan yang tidak mendapatkan penyuluhan.

Tabel. 1. Tingkat pengetahun siswa yang diberi peyuluhan dengan yang tidak diberi penyuluhan

\begin{tabular}{llcc}
\hline No & \multicolumn{1}{c}{ Pengetahuan } & $\begin{array}{c}\text { Min- } \\
\text { max }\end{array}$ & Mean \\
\hline 1 & $\begin{array}{l}\text { Kelompok yang } \\
\text { diberi penyuluhan }\end{array}$ & $3-8$ & 7,03 \\
2 & $\begin{array}{l}\text { Kelompok yang } \\
\text { tidak } \\
\text { penyuluhan diberi }\end{array}$ & $2-7$ & 5,63 \\
\hline
\end{tabular}

Berdasarkan tabel 1 terlihat perbedaan tingkat pengetahuan siswa antara siswa yang diberi penyuluhan dengan siswa yang tidak diberi penyuluhan. Meningkatkan pengetahuan diharapkan dapat meningkatkan sikap \& perilaku siswa untuk mengenali secara dini dan \& gejala penyakit keganasan pada anak \& remaja, sehingga bisa dilakukan deteksi dini sehingga penyakit dapat diidentifikasi segera dan dapat dilakukan penatalaksanaan secara capat \& tepat. Hal ini diharapkan dapat mencegah keterlambatan dalam penegakan diagnosa sehingga mencegah terjadinya komplikasi dan berlanjutnya penyakit ke tahap terminal. Dengan demikian dapat meningkatkan angka kesembuhan dan tingkat harapan hidup penderita.

Kemkes RI (2020) mengungkapkan penyakit keganasan pada anak seringkali sulit untuk segera dikenali. Hal ini disebabkan karena gejala awalnya seringkali mirip dengan penyakit lain yang lebih ringan. Kebanyakan di antaranya datang dengan stadium lanjut. Pada stadium lanjut, pengobatan terasa lebih berat karena penyakit telah menyebar ke banyak bagian tubuh sehingga menimbulkan gejala yang lebih berat. Harapan untuk penyembuhan juga lebih sulit pada penyakit kanker stadium lanjut. Pengenalan tanda-tanda penyakit keganasan sejak dini dapat meningkatkan angka kesembuhan dan harapan hidup anak yang mengalaminya.

Selain itu, tingginya tingkat pengetahuan siswa tentang penyakit keganasan pada anak \& remaja serta cara pencegahannya, meningkatkan motivasi siswa untuk memperbaiki pola hidup yang kurang sehat kepada pola hidup yang sehat sehingga dapat mencegah terjadinya penyakit kanker pada anak \& remaja.

\section{KESIMPULAN DAN SARAN}

\section{Kesimpulan}

Dengan adanya peningkatan pengetahuan diharapkan dapat meningkatkan sikap dan perilaku siswa untuk mengenali secara dini tanda \& gejala penyakit keganasan, sehingga bisa dilakukan penegakan doiagnosis dan penatalaksanaan secara capat \& tepat

\section{Saran}

Siswa disarankan memperbaiki pola hidup yang kurang sehat kepada pola hidup yang sehat sehingga dapat mencegah terjadinya penyakit kanker pada anak \& remaja

\section{UCAPAN TERIMAKASIH}

Ucapan terimakasih kami sampaikan kepada STIKes Garuda Putih Jambi yang mendanani kegiatan pengabdian masyarakat ini, Ketua LPPM yang memebri fasilitasi kegiatan pengabdian masyarakat, kepada kepala Sekolah beserta jajarannya SMAN Tititan Teras Jambi, dan mahasiswa yang .berpartisipasi dalam kegiatan pengabdian ini 


\section{DAFTAR PUSTAKA}

Behrman, R.E., Kliegman, R.M., \& Arvin, A.M (2000) Ilmu Kesehatan Anak Nelson (edisi 15 Volume 1) alih Bahasa : A Samik Wahab, Jakarta :EGC

Ikatan Dokter Anak Indonesia (2021) Kenali Tanda Awal Penyakit Keganasan Pada Anakhttps://www.idai.or.id/artikel/sep utar-kesehatan-anak/kenali-tandaawal-penyakit-keganasan-pada-anak

Kemenkes RI (2020) Kanker pada anakdpat perhatian khusus pemerintah

https://www.kemkes.go.id/article/vie w/17022400004/kanker-pada-anakdapat-perhatian-khususpemerintah.html

Notoatmodjo, S. 2010. Promosi kesehatan dan ilmu perilaku. Jakarta: Rineka Cipta

P2PTM Kemkes RI (2021) Kenali gejala dini kanker pada anak http://p2ptm.kemkes.go.id/kegiatanp2ptm/pusat-/kenali-gejala-dinikanker-pada-anak

Suryati, Rustina, Y., Nurhaini, N. (2011) Hubungan Koping orang tua dengan perkembangan anak dengan Leukemia Limfositik Akut (LLA) di RSAB Harapan Kita Jakarta. Tesis.

Wong D.L, Hockenberry, M., Wilson, D., Winkelstein, M.L., Schwartz, P. (2009) Buku Ajar Keperawatan Pediatrik Wong (ediai 6 volume 2) Alih Bahasa: Sutarna, A., Juniati, N. 7 kuncara, H.Y. Jakarta: EGC 